\title{
New insights on the importance of agency costs for corporate debt maturity decisions*
}

\author{
Yilmaz Guney \\ University of Surrey \\ Aydin Ozkan \\ University of York
}

Applied Financial Economics Letters, 2005, Volume 1, 233-238

\begin{abstract}
This paper provides new insights on the relationship between corporate debt maturity and agency costs by investigating empirically the impact of managerial ownership and the divergence between control and cash-flow rights on debt maturity. We observe a significant negative effect of managerial ownership on debt maturity. Moreover, the results reveal that the wedge between control and cash-flow rights also exerts a negative influence. Our analysis further suggests that the negative effect of managerial ownership decreases in widely-held firms and increases with the discrepancy between control and cash-flow rights.
\end{abstract}

JEL classification: G3; G32

Keywords: Debt maturity; agency costs; managerial ownership

\footnotetext{
We gratefully acknowledge helpful comments and suggestions from Mara Faccio, Gulcin Ozkan and participants at the 2002 METU International Economics Symposium and the University of York. We are indebted to Mara Faccio and Larry Lang for the data on the ultimate ownership and control of UK firms. The standard disclaimer applies.
} 


\section{Introduction}

The relationship between debt maturity and agency costs of corporate financial decisions has been an important issue in the capital structure literature. Specific attention, in this context, has been paid to the role of debt maturity in reducing the socalled underinvestment problem, described in Myers (1977), which arise from the agency conflicts between a firm's shareholders and debtholders. It is widely acknowledged that short-term debt may be more effective than long-term debt in reducing the expected agency costs of the underinvestment problem.

However, prior empirical research on debt maturity does not say much on the implications of the potential interactions between debt maturity and other central agency conflicts within the firm. For example, to our knowledge, there is no previous empirical work that investigates the effects of the fundamental agency problem of the separation of ownership and control on debt maturity structure. Similarly, the influence of managerial incentives on debt maturity has not been investigated. This paper therefore aims to provide new insights on such issues by taking a closer look at managerial ownership and the divergence between control and cash flow rights. By doing so, this paper extends the earlier analyses and enhances our understanding of the role agency concerns play in determining debt maturity decisions.

To investigate these issues empirically, we use a sample of $771 \mathrm{UK}$ firms. Our results point to a significant negative influence of managerial ownership on debt maturity. However, managers in widely-held firms tend to hold more long-term debt. We also find that firms with greater divergence between control and cash-flow rights seem to hold more short-term in their capital structure. Furthermore, the results reveal that the negative impact of managerial ownership on debt maturity increases with the discrepancy between control and cash-flow rights.

The paper is organised as follows. Section 2 outlines the possible theoretical interactions between managerial incentives, divergence between control and cash-flow rights and debt maturity. Section 3 briefly explains other control variables used in the empirical analysis. Section 4 explains the data, which is followed by presenting the results. Finally, section 6 concludes the paper. 


\section{Debt maturity and ownership characteristics}

The underinvestment problem of Myers (1977), which has received a great deal of attention in the corporate finance literature, is due to the outstanding debt in the firm's capital structure. The agency problem arises between shareholders and debtholders because firms with risky debt may have incentives to pass up some of the valuable growth options. One of the mechanisms to address the underinvestment problem is the firm's debt maturity structure. It is argued that firms with greater growth opportunities should have more short-term debt because shortening debt maturity would make it more likely that debt will mature before any opportunity to exercise the growth options. ${ }^{1}$

Another central issue relating to agency conflicts concerns the role of managerial ownership and managerial discretion in influencing financing and investment decisions of firms. Prior research points out that the firm's resources may be diverted by managers for their private benefits (Jensen and Meckling, 1976; and Jensen, 1986). This can take alternative forms such as excessive salaries, dilution of the ownership of outsiders, and commitment of resources to unprofitable investment projects.

We note that the severity of agency conflicts between managers and shareholders is likely to differ across firms depending on managerial shareholdings. It is argued that as managerial ownership increases, the ability of outside investors to monitor managers declines. This, in turn, may lead to a greater degree of managerial control and entrenchment of managers (McConnell and Servaes, 1990). Accordingly, managerial ownership may act as a proxy for the conflicts of interests between managers and outside shareholders, and the associated costs. Furthermore, shortening debt maturity can be effective because it can act as a disciplinary device on managers as it increases the risk of liquidity and premature liquidation of the firm's assets. ${ }^{2}$ This line of argument leads to the following hypothesis.

Prediction 1. There is a negative relationship between managerial ownership and debt maturity. ${ }^{3}$

\footnotetext{
${ }^{1}$ Consistent with this prediction, there are studies that find a negative relation between maturity and growth opportunities (see, e.g., Barclay and Smith, 1995; Guedes and Opler, 1996; and Ozkan, 2000, among others).

${ }^{2}$ See Johnson (2003) for further discussion on the relationship between debt maturity and liquidity risk.

${ }^{3}$ In addition to the expected agency benefits of shorter-term debt, in increasing short-term debt managers may also consider the benefits due to the reduction in the likelihood of takeover attempts.
} 
However, we do not rule out the possibility that managers may also have incentives to have more long-term debt than optimal in some circumstances. For example, to the extent that managers of widely-held firms have greater discretion, one could argue that managers in such firms may attempt to escape the discipline provided by short-term debt and hence issue more long-term debt. This reduces the probability of bankruptcy and may enable managers to use excess cash for their benefit. This can happen even if short-term debt is more beneficial to an average shareholder in the presence of costly agency conflicts. The benefits to managers through the reduced expected agency costs would be limited because, by definition, their shareholdings in widely-held firms are relatively small. The above discussion leads to the following prediction.

Prediction 2. In widely-held firms, the negative impact of managerial ownership on debt maturity decreases.

Furthermore, we recognise that there are other measures that can be used to proxy for agency costs. For example, one such measure is the discrepancy between ownership (cash-flow rights) and control-rights. It is argued that the agency costs in firms with greater discrepancy are expected to be higher (Harvey et al., 2004). This is mainly because cash-flow rights of shareholders are related to the positive incentive effect, while control-rights relate to the negative entrenchment effect on firm value (see, e.g., Claessens et al., 2002). Then, one would expect firms with shareholders whose cashflow rights are significantly less than their control-rights to choose more short-term debt in an attempt to curtail the negative impact of agency costs on firm value.

Prediction 3. There is a negative relationship between the divergence between control-rights and cash-flow rights of shareholders and debt maturity.

\section{Other control variables}

In what follows, we briefly explain the control variables used in the empirical analysis.

Leverage. Bankruptcy concerns due to high leverage may cause long-term debt choice to hedge against bankruptcy risk (Morris, 1992). However, leverage and maturity can be negatively related as agency costs of underinvestment can be mitigated by 
reducing leverage as well as shortening maturity (Dennis et al., 2000). We measure leverage as the ratio of book value of total debt to total assets.

Liquidity. Due to their ability to meet borrowing restrictions, firms with higher liquidity balances will be able to lengthen their debt maturity (Morris, 1992). This would imply a positive relation between liquidity and maturity. We measure liquidity as the ratio of current assets to current liabilities.

Asset Maturity. Myers (1977) argues that the underinvestment problem can be reduced by matching the maturity of a firm's debt to that of its assets. This leads us to predict a positive relationship between debt and asset maturities. We measure asset maturity as the ratio of net property, plant and equipment to annual depreciation expenses.

Earnings Variability. The association of debt maturity with earnings variability is expected to be inverse so that the firm does not have to rebalance its capital structure as often to moderate expected bankruptcy costs when the earnings volatility decreases. Variability in earnings is measured as the standard deviation of earnings before interest, tax and depreciation (EBITD) divided by average total assets.

Growth opportunities. It is suggested that firms with more growth options are associated with more use of short-term debt in their debt maturity mix (Myers, 1977). The counter argument, however, is that firms with substantial growth opportunities might borrow long-term to avoid liquidation of their valuable projects (Diamond, 1991). Growth opportunities are measured by the market-to-book ratio, which is the book value of total assets minus the book value of equity plus the market value of equity to book value of total assets.

Size. Smaller firms with potentially severe agency problems have much more difficult access to the capital markets, which proposes a direct relation between firm size and debt maturity. Firm size is measured as logarithm of total assets in 1996 prices.

\section{Data Description}

We use a sample of listed UK firms for the period from 1996 to 2000. Data for the shareholdings of directors and company accounts were collected from Datastream. Data for the ultimate controllers of firms were obtained from Faccio and Lang (2002). After some data filtering, we were left with 771 matched firms for our analysis. 
Table 1 provides a brief analysis of the ultimate ownership structure of the UK companies included in our sample. Companies are mainly classified into two groups: widely-held, which have no owners with significant control rights, and those with controlling owners. We report results for two different cut-off levels for controllers, namely 10 and 20 percent thresholds (for a detailed discussion see Faccio and Lang, 2002). Also, controlling owners are further classified into six categories: widely-held corporations, financial institutions, family, unlisted companies, state, and miscellaneous.

\section{[INSERT TABLE 1 HERE]}

In Panel A of Table 1 we present percentage and number of firms controlled by different categories of owners at both cut-off levels. At the 10 percent level, only 24.36 percent of firms are widely-held. Family-controlled firms comprise 26.67 percent of firms in our sample, which makes it the largest category. Furthermore, 20.38 percent of firms are controlled by financial institutions. Another important category is the unlisted companies that control 18.72 percent of firms.

In Panel B we report summary statistics on the control rights of the largest controlling owner in each category of controller, where the ultimate control threshold is 10 percent. The average percentage values of control rights of the largest controlling shareholder are 38.35 and 29.52 for firms that are controlled by widely-held corporations and family, respectively. The average percentage is 20.20 percent for firms where the largest controlling shareholder is a financial institution.

Table 2 provides descriptive statistics for the variables used in the analysis. The average long-term debt, defined as the ratio of debt matures in more than one year to total debt, is about 52 percent. The table also reveals that, on average, directors own about 12 percent of total shareholdings in the UK companies. Finally, the mean ratio of control rights to cash-flow rights is nearly 1.72 .

[INSERT TABLE 2 HERE]

\section{Empirical Results}

In the following we provide the results of several cross-sectional debt maturity models using the average values of the explanatory variables (except variability and ownership variables) over the period 1996-1999 and we measure the dependent variable (debt maturity) in 2000. We do so in an attempt to mitigate problems that might arise due to short-term fluctuations or extreme values in one year. Using past values also 
reduces the likelihood of observed relations reflecting the effects of debt maturity on firm-specific factors (see also Rajan and Zingales, 1995, for a similar methodology). Ownership variables are measured in 1997. Given that equity ownership structure of firms is relatively stable over a certain period of time, we do not expect that measuring ownership characteristics in a single year would yield a significant bias in our results (see also La Porta et al., 2002, among others).

\section{[INSERT TABLE 3 HERE]}

Under all specifications in Table 3, debt maturity decisions are proxied by the ratio of debt that matures in more than one year to total debt. We begin our investigation of the agency determinants of debt maturity decision by focusing on the impact of managerial shareholdings. In column (1) of Table 3, we report the regression results for the basic model that includes the control variables described earlier and the managerial ownership variable (Man_Own). The results reveal that the impact of managerial ownership on debt maturity is negative and significant (at $5 \%$ level). This can be taken as evidence for the view that firms prefer more short-term debt when the expected agency costs of managerial ownership are higher. ${ }^{4}$ As also mentioned earlier, the negative effect may be due to the managerial incentives to reduce the likelihood of takeover attempts by making the firm riskier to outside investors.

In column (2), we additionally test whether the debt maturity decisions of widelyheld firms are different from those of the firms with controllers. We also test if the negative impact of managerial ownership changes in widely-held firms. To do so, we incorporate two additional variables into the model, namely Widely_Held, a dummy variable that takes a value of one if the firm is widely-held, and an interaction variable Man_Own * Widely_Held to measure the conditional impact of managerial ownership on the firm's debt maturity structure. This would allow us to test if the effect of managerial ownership varies between widely-held and controlled firms.

The results for model (2) suggest that the main effect of managerial ownership is still negative but the conditional effect is positive and significant (at $10 \%$ level). This

\footnotetext{
${ }^{4}$ We note that the relationship between managerial ownership and debt maturity can be non-monotonic, implying that the marginal effect of increased managerial ownership depends on the level of managerial ownership. This implies that at lower levels of managerial ownership the interests of managers and outside shareholders may be aligned. To test this possibility, we also estimated a quadratic model that predicts that as managerial ownership increases, we expect to observe first a positive (incentivealignment), then a negative (entrenchment) effect exerted by managerial ownership on debt maturity. However, we do not find any meaningful non-linear impact of managerial ownership and hence do not report the results.
} 
suggests that the negative impact of managerial ownership on debt maturity decreases in widely-held firms. As discussed earlier, managerial discretion in widely-held firms may be greater and hence managers of such firms may prefer to issue more long-term debt.

In order to provide more insight into the impact of agency costs on debt maturity structure we present in column (3) the results with an additional variable (Divergence) that measures the wedge between control and cash-flow rights. The estimated coefficient of this variable is negative and significant (at $1 \%$ level), possibly providing further evidence for the notion that, other things being equal, firms with greater expected agency costs prefer short-term debt to mitigate the negative effects of these costs on firm value. This also points to the effective role of debt maturity as an internal corporate governance mechanism.

Finally, we examine in column (4) whether the impact of managerial ownership on debt maturity changes with the discrepancy between control and cash-flow rights of large shareholders by interacting Man_Own with Divergence. The estimated coefficient is negative and significant (at $5 \%$ level), suggesting that the negative impact of managerial ownership on debt maturity is greater in firms where the divergence between control and cash-flow rights is larger. In other words, managers of firms with greater discrepancy between control and cash-flow rights of shareholders prefer to have more short-term debt. This is possibly due to an increase in the expected costs of managerial ownership arising from reduced incentives of large shareholders to control the management.

\section{Conclusions}

This paper provides new results with regard to the impact of agency costs on corporate debt maturity. In doing so, specific attention is paid to relation between debt maturity and managerial ownership and divergence between control and cash-flow rights of large shareholders. Our main finding is that managerial ownership plays an important role in determining debt maturity. The findings reveal that there is a negative relationship between managerial ownership and debt maturity. However, the negative impact decreases in widely-held firms. The results also reveal a negative relationship between debt maturity and the ratio of control rights to cash flow rights. Furthermore, the negative impact of managerial ownership on debt maturity increases when the divergence increases. 
The results of this analysis suggest that the agency conflict between shareholders and debtholders, i.e. the underinvestment problem, may not be the only agency factor that affects debt maturity decisions. It seems that one needs to consider other potential agency problems, namely the one between insiders (managers) and outside investors, in analysing corporate debt maturity decisions.

\section{References}

Barclay, M. J. and Smith, C. W. (1995), The maturity structure of corporate debt, Journal of Finance 50, 609-631.

Claessens, S., Djankov, S., Fan, J.P.H., and Lang, L. (2002), Disentangling the incentive and entrenchment effects of large shareholdings, Journal of Finance 57, 27412771.

Dennis, S., Nandy, D. and Sharpe, I.G. (2000), The determinants of contract terms inbank revolving credit agreements, Journal of Financial and Quantitative Analysis 35, 87-110.

Diamond, D.W. (1991), Debt maturity structure and liquidity risk, Quarterly Journal of Economics 106, 709-737.

Faccio, M. and Lang, L.H.P. (2002), The ultimate ownership of Western European corporations, Journal of Financial Economics 65, 365-395.

Guedes, J. and Opler, T. (1996), The determinants of the maturity of corporate debt issues, Journal of Finance 51, 1809-1834.

Harvey, C.R., Lins, K.V. and Roper, A.H. (2004), The effects of capital structure when expected agency costs are extreme, Journal of Financial Economics 74, 3-30.

Jensen, M.C., 1986. Agency costs of free cash flow, corporate finance and takeovers. American Economic Review 76, 323-39.

Jensen, M.C., Meckling, W.H., 1976. Theory of the firm: Managerial behavior, agency costs and ownership structure. Journal of Financial Economics 3, 305-360.

Johnson, S.A. (2003), Debt maturity and the effects of growth opportunities and liquidity risk on leverage, Review of Financial Studies 16, 209-236.

La Porta, R., Lopez-de-Silanes, F., Shleifer, A., Vishny, R.W. (2002), Investor protection and corporate valuation, Journal of Finance 57, 1147-1170.

McConnell, J. and Servaes, H. (1990), Additional evidence on equity ownership and corporate value, Journal of Financial Economics 27, 595-612. 
Morris, J.R. (1992), Factors affecting the maturity structure of corporate debt, Working Paper, College of Business and Administration, University of Colorado at Denver.

Myers, S.C. (1977), Determinants of corporate borrowing, Journal of Financial Economics 5, 147-175.

Ozkan, A. (2000), An empirical analysis of corporate debt maturity structure, European Financial Management 6, 197-212.

Rajan, R.G. and Zingales, L. (1995), What do we know about capital structure? Some evidence from international data, Journal of Finance 50, 1421-1460. 
Table 1

Ultimate Controllers of UK Companies

Panel A: Percentage of firms controlled by different owners ${ }^{a}$

\begin{tabular}{lccccccc}
\hline & $\begin{array}{c}\text { Widely- } \\
\text { held }\end{array}$ & $\begin{array}{c}\text { Widely-held } \\
\text { Corporation }\end{array}$ & $\begin{array}{c}\text { Financial } \\
\text { Institutions }\end{array}$ & Family & $\begin{array}{c}\text { Unlisted } \\
\text { Company }\end{array}$ & State & Miscel. \\
$10 \%$ Cutoff & 24.36 & 0.64 & 20.38 & 26.67 & 18.72 & 0.13 & 9.10 \\
No. of Firms & 190 & 5 & 159 & 208 & 146 & 1 & 71 \\
20 \% Cutoff & 67.44 & 0.51 & 6.53 & 15.64 & 6.41 & 0 & 3.47 \\
No. of Firms & 526 & 4 & 51 & 122 & 50 & 0 & 27 \\
\hline
\end{tabular}

Panel B: Descriptive statistics of ultimate ownership by different groups ${ }^{b}$

\begin{tabular}{lccccccc}
\hline & $\begin{array}{c}\text { Widely } \\
\text { held }\end{array}$ & $\begin{array}{c}\text { Widely-held } \\
\text { Corporation }\end{array}$ & $\begin{array}{c}\text { Financial } \\
\text { Institutions }\end{array}$ & Family & $\begin{array}{c}\text { Unlisted } \\
\text { Company }\end{array}$ & State & Miscel. \\
Mean & 0.72 & 38.35 & 20.20 & 29.52 & 24.71 & 13.87 & 21.31 \\
Min & 0 & 11.07 & 10.09 & 10.13 & 10.25 & 13.87 & 10.30 \\
$25 \%$ & 0 & 20.60 & 11.40 & 15.65 & 15.74 & 13.87 & 14.08 \\
Median & 0 & 29.79 & 16.18 & 24.46 & 15.74 & 13.87 & 15.1 \\
$75 \%$ & 0 & 65.01 & 23.10 & 40.09 & 26.01 & 13.87 & 33.28 \\
Max & 9.48 & 65.30 & 89.90 & 84.50 & 86.88 & 13.87 & 58.90 \\
\hline
\end{tabular}

This table presents summary statistics on ultimate controllers for a sample of 780 UK firms in 1997. $a$ : based on the ownership of the largest control holder.

$b$ : at the 10 percent ultimate control threshold.

Source: Our own calculations based on the ultimate ownership data in Faccio and Lang (2002).

Table 2

Descriptive Statistics

\begin{tabular}{lcccccc}
\hline & Mean & Min & $25 \%$ & Median & $75 \%$ & Max \\
\hline & & & & & & \\
Maturity & 0.518 & 0 & 0.217 & 0.555 & 0.812 & 1 \\
Leverage & 0.161 & 0 & 0.077 & 0.154 & 0.222 & 0.842 \\
Market-to-Book & 1.845 & 0.351 & 1.047 & 1.411 & 1.970 & 25.161 \\
Size & 9.431 & 2.338 & 8.178 & 9.292 & 10.543 & 15.633 \\
Asset Maturity & 11.893 & 0.948 & 5.901 & 8.253 & 11.750 & 131.62 \\
Variability & 0.075 & 0.005 & 0.039 & 0.061 & 0.093 & 0.814 \\
Liquidity & 1.633 & 0.224 & 1.097 & 1.366 & 1.772 & 28.23 \\
Man_Own & 0.119 & 0 & 0.004 & 0.037 & 0.173 & 0.844 \\
Divergence & 1.717 & 0 & 1 & 1 & 1.019 & 10.26 \\
\hline
\end{tabular}

Maturity is defined as the ratio of debt that matures in more than one year to total debt. Leverage is the ratio of book value of total debt to book value of total assets. Market-to-Book is the ratio of book value of total assets minus the book value of equity plus the market value of equity to book value of total assets. Size is the natural logarithm of total assets in 1996 prices. Asset Maturity is the ratio of net property, plant and equipment to annual depreciation expense. Variability is the standard deviation of earnings before interest, tax and depreciation (EBITD) divided by average total assets. Liquidity is the ratio of current assets to current liabilities. Man_Own is the total percentage of equity ownership by directors. Divergence is the ratio of control rights to cash flow rights. 
Table 3

Corporate ownership and corporate debt maturity mix

\begin{tabular}{|c|c|c|c|c|}
\hline \multicolumn{5}{|c|}{ Dependent variable: Maturity } \\
\hline & (1) & (2) & (3) & (4) \\
\hline \multirow[t]{2}{*}{ Leverage } & $0.6085^{* * * *}$ & $0.6118^{* * * *}$ & $0.6136^{* * * *}$ & $0.6126^{* * *}$ \\
\hline & $(0.1203)$ & $(0.1203)$ & $(0.1204)$ & $(0.1203)$ \\
\hline \multirow[t]{2}{*}{ Market-to-Book } & $0.0198^{* * *}$ & $0.0201^{* * *}$ & $0.0199^{* * *}$ & $0.0199^{* * *}$ \\
\hline & $(0.0074)$ & $(0.0075)$ & $(0.0075)$ & $(0.0075)$ \\
\hline \multirow[t]{2}{*}{ Size } & $0.0347^{* * *}$ & $0.0358^{* * *}$ & $0.0356^{* * *}$ & $0.0359^{* * *}$ \\
\hline & $(0.0065)$ & $(0.0067)$ & $(0.0067)$ & $(0.0067)$ \\
\hline \multirow[t]{2}{*}{ Asset Maturity } & $0.0033^{* *}$ & $0.0033^{* * *}$ & $0.0033^{* * *}$ & $0.0033^{* * *}$ \\
\hline & $(0.0013)$ & $(0.0013)$ & $(0.0013)$ & $(0.0013)$ \\
\hline \multirow[t]{2}{*}{ Earnings Variability } & -0.0030 & -0.0029 & -0.0029 & -0.0030 \\
\hline & $(0.0020)$ & $(0.0020)$ & $(0.0020)$ & $(0.0020)$ \\
\hline \multirow[t]{2}{*}{ Liquidity } & $0.0251^{*}$ & $0.0262^{*}$ & $0.0262^{*}$ & $0.0262^{*}$ \\
\hline & $(0.0140)$ & $(0.0141)$ & $(0.0141)$ & $(0.0141)$ \\
\hline \multirow[t]{2}{*}{ Man_Own } & $-0.1624^{* *}$ & $-0.2272^{* * *}$ & $-0.2272^{* * *}$ & $-0.2323^{* * * *}$ \\
\hline & $(0.0736)$ & $(0.0852)$ & $(0.0853)$ & $(0.0850)$ \\
\hline \multirow[t]{2}{*}{ Widely_Held } & - & -0.0012 & 0.0004 & -0.0324 \\
\hline & & $(0.0305)$ & $(0.0305)$ & $(0.0351)$ \\
\hline \multirow[t]{2}{*}{ Man_Own* Widely_Held } & - & $0.2963^{*}$ & $0.2910^{*}$ & $0.2984^{*}$ \\
\hline & & $(0.1577)$ & $(0.1576)$ & $(0.1575)$ \\
\hline \multirow[t]{2}{*}{ Divergence } & - & - & $-0.0011^{* * *}$ & $-0.0010^{* * *}$ \\
\hline & & & $(0.0002)$ & $(0.0002)$ \\
\hline \multirow[t]{2}{*}{ Man_Own*Divergence } & - & - & - & $-0.0256^{* *}$ \\
\hline & & & & $(0.0113)$ \\
\hline \multirow[t]{2}{*}{ Constant } & -0.0094 & -0.0300 & -0.0274 & 0.0031 \\
\hline & $(0.0791)$ & $(0.0796)$ & $(0.0796)$ & $(0.0809)$ \\
\hline No. of observations & 771 & 771 & 771 & 771 \\
\hline Adjusted $R^{2}$ & 0.1590 & 0.1630 & 0.1642 & 0.1649 \\
\hline
\end{tabular}

Maturity is defined as the ratio of debt that matures in more than one year to total debt. Leverage is the ratio of book value of total debt to book value of total assets. Market-toBook is the ratio of book value of total assets minus the book value of equity plus the market value of equity to book value of total assets. Size is the natural logarithm of total assets in 1996 prices. Asset Maturity is the ratio of net property, plant and equipment to annual depreciation expense. Earnings Variability is the standard deviation of EBITD divided by average total assets. Liquidity is the ratio of current assets to current liabilities. Man_Own is the total percentage of equity ownership by directors. Widely_Held takes the value of 1 if the firm has no controller. Divergence is the ratio of control rights to cash flow rights. Standard errors robust to heteroscedasticity are in the parentheses. $(*),(* *)$ and $(* * *)$ show that the estimated coefficients are significant at $10 \%, 5 \%$ and $1 \%$ level. 